\title{
Bombyx batryticatus Protein-Rich Extract Induces Maturation of Dendritic Cells and Th1 Polarization: A Potential Immunological Adjuvant for Cancer Vaccine
}

\author{
Ha-Yeon Song ${ }^{1,2,+}$, Jeong Moo Han ${ }^{1,2,+}$, Eui-Hong Byun ${ }^{3}$, Woo Sik Kim ${ }^{4}$, Ho Seong Seo ${ }^{1}$ and Eui-Baek Byun ${ }^{1, *}$ \\ 1 Research Division of Radiation Science, Advanced Radiation Technology Institute, Korea Atomic Energy \\ Research Institute, Jeougeup 56212, Korea; songhy@kaeri.re.kr (H.-Y.S.); jmhahn@kaeri.re.kr (J.M.H.); \\ seohoseong@kaeri.re.kr (H.S.S.) \\ 2 Department of Biotechnology, College of Life Science and Biotechnology, Korea University, Seoul 02841, Korea \\ 3 Department of Food Science and Technology, Kongju National University, Yesan 32439, Korea; \\ ehbyun80@kongju.ac.kr \\ 4 Functional Biomaterial Research Center, Korea Research Institute of Bioscience and Biotechnology, \\ Jeoupeup 56212, Korea; kws6144@kribb.re.kr \\ * Correspondence: ebbyun80@kaeri.re.kr; Tel.: +82-63-570-3773; Fax: +82-63-570-3371 \\ + These authors contributed equally to this work.
}

check for updates

Citation: Song, H.-Y.; Han, J.M.; Byun, E.-H.; Kim, W.S.; Seo, H.S.; Byun, E.-B. Bombyx batryticatus Protein-Rich Extract Induces Maturation of Dendritic Cells and Th1 Polarization: A Potential Immunological Adjuvant for Cancer Vaccine. Molecules 2021, 26, 476. https://doi.org/10.3390/ molecules 26020476

Academic Editor: Roberto Fabiani Received: 28 December 2020

Accepted: 14 January 2021

Published: 18 January 2021

Publisher's Note: MDPI stays neutral with regard to jurisdictional claims in published maps and institutional affiliations.

Copyright: (c) 2021 by the authors. Licensee MDPI, Basel, Switzerland. This article is an open access article distributed under the terms and conditions of the Creative Commons Attribution (CC BY) license (https:// creativecommons.org/licenses/by/ $4.0 /)$.

\begin{abstract}
Bombyx batryticatus, a protein-rich edible insect, is widely used as a traditional medicine in China. Several pharmacological studies have reported the anticancer activity of $B$. batryticatus extracts; however, the capacity of $B$. batryticatus extracts as immune potentiators for increasing the efficacy of cancer immunotherapy is still unverified. In the present study, we investigated the immunomodulatory role of $B$. batryticatus protein-rich extract (BBPE) in bone marrow-derived dendritic cells (BMDCs) and DC vaccine-immunized mice. BBPE-treated BMDCs displayed characteristics of mature immune status, including high expression of surface molecules (CD80, CD86, major histocompatibility complex (MHC)-I, and MHC-II), increased production of proinflammatory cytokines (tumor necrosis factor- $\alpha$ and interleukin-12p70), enhanced antigen-presenting ability, and reduced endocytosis. BBPE-treated BMDCs promoted naive $\mathrm{CD}^{+}{ }^{+}$and $\mathrm{CD} 8^{+}$T-cell proliferation and activation. Furthermore, BBPE/ovalbumin (OVA)-pulsed DC-immunized mice showed a stronger OVA-specific multifunctional $\mathrm{T}$-cell response in $\mathrm{CD}^{+}$and $\mathrm{CD} 8^{+} \mathrm{T}$ cells and a stronger Th1 antibody response than mice receiving differently treated DCs, which showed the enhanced protective effect against tumor growth in E.G7 tumor-bearing mice. Our data demonstrate that BBPE can be a novel immune potentiator for a DC-based vaccine in anticancer therapy.
\end{abstract}

Keywords: Bombyx batryticatus extract; dendritic cells; cancer vaccine; multifunctional T cells; aminoacid composition; immunopotentiator

\section{Introduction}

Cancer immunotherapy has emerged as a powerful weapon for eradicating malignant tumors. It offers numerous advantages compared to chemotherapy, radiotherapy, and traditional surgery, such as strong efficacy against certain cancers, fewer side effects, and potential of combination therapy [1,2]. There are several classes of cancer immunotherapy, including immune checkpoint blockade therapy, chimeric antigen receptor (CAR) T-cell therapy, and cancer vaccine [3-5]. Among these, vaccination with dendritic cells (DCs) is an effective approach to overcome the immunosuppressive microenvironment, as well as initiate antitumor-specific immune responses [6,7]. The first step of DC vaccination is maturation of DCs isolated from autologous peripheral blood mononuclear cells (PBMCs) using tumor-associated antigens. Following maturation, DCs are re-administered to the patients to induce antitumor immunity [8]. A successful therapeutic vaccine mostly depends on generating cytotoxic T lymphocytes (CTLs) that specifically recognize and directly kill 
cancer cells [9]. However, tumor antigens often induce tolerogenicity to host immunity via downregulation of major histocompatibility complex (MHC) molecules to evade recognition and upregulation of immune inhibitory receptors [10]. Due to these complications, immunostimulatory adjuvants are considered a promising strategy to overcome these impediments toward effective cancer vaccines.

Immunostimulatory adjuvants enable solving the problems of immunosuppression and low antigenicity of tumor antigens by inducing a more rapid immune response, such as a strong antibody response and effective T-cell response [11]. The adjuvants can be divided into three types, including delivery systems, immune potentiators, and mucosal adjuvants [12]. Immune potentiators generally target innate immunity signaling pathways by inducing activation and maturation of antigen-presenting cells. Consequently, combination with immune potentiators contributes to long-lasting immunity via increasing the efficacy of DC vaccines [13]. Unfortunately, some side effects of immune potentiators have been suggested (e.g., toxicity, splenomegaly, lymphoid follicle destruction, and immunosuppression) [14]. Therefore, several studies have focused on developing new and safe immune potentiators from natural ingredients [15].

As edible insects are being considered as an attractive protein source, application of these edible insects as medicine or nutrition supplement has been actively sought [16]. Bombyx batryticatus (B. batryticatus), a popular insect used as traditional medicine in China, originates from the dried stiff larval stage of Bombyx mori L. infected by Beauveria bassiana [17]. The pharmacological effects of B. batryticatus extracts, such as their antibacterial, neuroprotective, and antioxidant activity, have been widely studied [18-20]. In particular, recent studies suggested that $B$. batryticatus extracts show strong antitumor activities in various cancer cells, in addition to their potential to regulate the tumor microenvironment via macrophage polarization toward the M1 phenotype, which plays a role in antitumor immunity $[17,18,21,22]$. B. batryticatus contains various nutritional constituents, including proteins, peptides, polysaccharides, flavonoids, fatty acids, and others. Of these, the principal constituents are proteins, which account for $40-70 \%$ of total components [23]. Nevertheless, there is no evidence yet supporting the effects of B. batryticatus protein extracts on the physiological activities of immune cells.

Here, we investigated whether B. batryticatus extracts that are rich in proteins would induce DC maturation in vitro and consequently enhance antigen-specific anticancer immunity in a DC vaccine mouse model.

\section{Results}

\subsection{Amino-Acid Composition of BBPE}

Dietary supplementation with high-quality protein helps to strengthen immune function [24]. Amino-acid composition is an important determinant of the nutritional value of protein. The amino-acid profile of BBPE is presented in Table 1. BBPE contains a balanced content of essential amino acids and nonessential amino acids, with the exception of tryptophan. In BBPE, the content of glutamine and glutamate was highest, followed by alanine, while the histidine content was lowest. In particular, BBPE contains a considerable content of branched-chain amino acids (valine, leucine, and isoleucine), glutamine, and arginine, which are important immuno-nutrients. To investigate whether the nutritional value of BBPE affects the immunological advantage, the phenotypic and functional changes by BBPE in BMDCs were investigated. 
Table 1. Amino-acid composition of Bombyx batryticatus protein-rich extract (BBPE).

\begin{tabular}{cccc}
\hline Essential Amino Acid $\mathbf{( m g / g )}$ & \multicolumn{1}{c}{ Nonessential Amino Acid (mg/g) } \\
\hline Histidine & 1.88 & Cysteine & 2.60 \\
Threonine & 11.28 & Aspartate + Asparagine & 21.18 \\
Valine & 16.12 & Glutamine + Glutamate & 58.89 \\
Methionine & 2.82 & Serine & 17.09 \\
Isoleucine & 10.56 & Glycine & 21.14 \\
Leucine & 15.62 & Arginine & 27.47 \\
Phenylalanine & 6.24 & Alanine & 35.11 \\
Tryptophan & N.D. & Proline & 19.22 \\
Lysine & 14.51 & Tyrosine & 5.66 \\
Sum of EAA & 79.02 & Sum of NEAA & 208.37
\end{tabular}

All amino acid values are expressed as milligram per $g$ of protein. EAA, essential amino acid; NEAA, nonessential amino acid; N.D., not detected.

\subsection{B. batryticatus Protein Extract (BBPE) Induces Phenotypic Maturation of BMDCs and Th1 Polarization}

Upon maturation, DCs begin to synthetize peptides presented by MHC molecules, along with co-stimulatory molecules, and they produce high levels of proinflammatory cytokines to induce T-cell-mediated immune responses [25]. Prior to investigating the effects of BBPE on DC maturation, cell viability was analyzed to determine noncytotoxic concentrations of BBPE. BBPE treatment was not toxic to BMDCs at concentrations ranging from 10 to $100 \mu \mathrm{g} / \mathrm{mL}$ (Figure 1A,B). We next investigated whether BBPE can induce DC maturation. First, the expression of co-stimulatory molecules and MHC receptors in the presence of BBPE $(10,50$, or $100 \mu \mathrm{g} / \mathrm{mL})$ or lipopolysaccharide (LPS) $(100 \mathrm{ng} / \mathrm{mL}$; a positive control for DC maturation) was analyzed by flow cytometry. As shown in Figure 1C, treatment with BBPE significantly increased the expression of CD80, CD86, MHC class I, and MHC class II in a dose-dependent manner. Next, we examined the production of pro- and anti-inflammatory cytokines. BBPE treatment strongly induced the production of Th1-polarizing cytokines, including tumor necrosis factor (TNF- $\alpha$ ) and interleukin (IL)-12p70), while it did not affect anti-inflammatory cytokine IL-10 levels (Figure 2A). The finding that BBPE only increased Th1-polarizing cytokine levels was also confirmed by intracellular cytokine staining (Figure 2B). Taken together, these results strongly indicate that BBPE can induce polarization toward the Th1 phenotype, as well as maturation of BMDCs.

\subsection{BBPE Increases Antigen-Presenting Ability of BMDCs and Reduction of Endocytosis}

Mature DCs display incompetent endocytosis, while they generally have strong antigen-presenting ability [26]. To determine the endocytosis capacity of BMDCs after BBPE treatment, the uptake of fluorescein isothiocyanate (FITC)-dextran by BMDCs was examined using flow cytometry. The group treated with $100 \mu \mathrm{g} / \mathrm{mL}$ of BBPE showed a lower percentage of double-positive $\left(\mathrm{CD} 11 \mathrm{c}^{+}\right.$and dextran-FITC ${ }^{+}$) cells than the control group (Figure $3 \mathrm{~A}$ ). We next investigated the exogenous antigen-presenting ability of BMDCs using flow cytometry. The percentage of cells positive for 25-D1.16, which recognizes MHC class I-associated ovalbumin (OVA) $257-264$, was higher in groups co-treated with OVA protein and $50 \mu \mathrm{g} / \mathrm{mL}$ BBPE than in those treated with OVA only (Figure 3B). Furthermore, the percentage of cells positive for Y-Ae that reacts with $\mathrm{E} \alpha_{52-68}$ peptide (MHC class-II) was higher in groups co-treated with $\mathrm{E} \alpha_{44-76}$ peptide and $50 \mu \mathrm{g} / \mathrm{mL}$ BBPE than in those treated with $\mathrm{E} \alpha_{44-76}$ peptide only (Figure $3 \mathrm{C}$ ). 
A
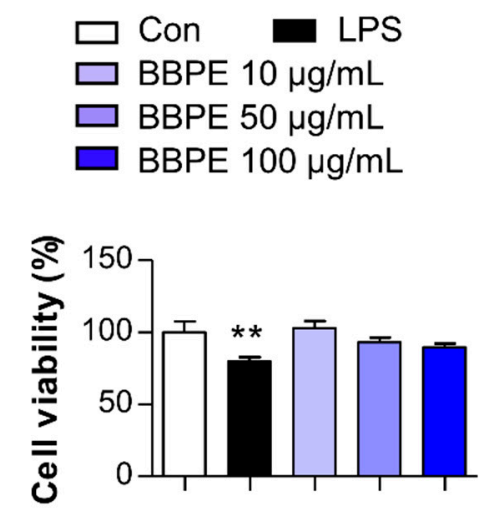

B

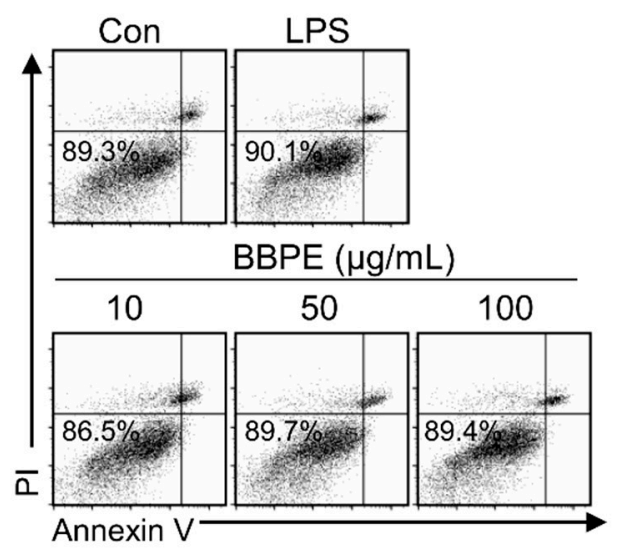

C

$\square$ Con $\square$ LPS $\square$ BBPE $10 \mu \mathrm{g} / \mathrm{mL} \square$ BBPE $50 \mu \mathrm{g} / \mathrm{mL} \square \mathrm{BBPE} 100 \mu \mathrm{g} / \mathrm{mL}$

Gated on CD11c ${ }^{+}$
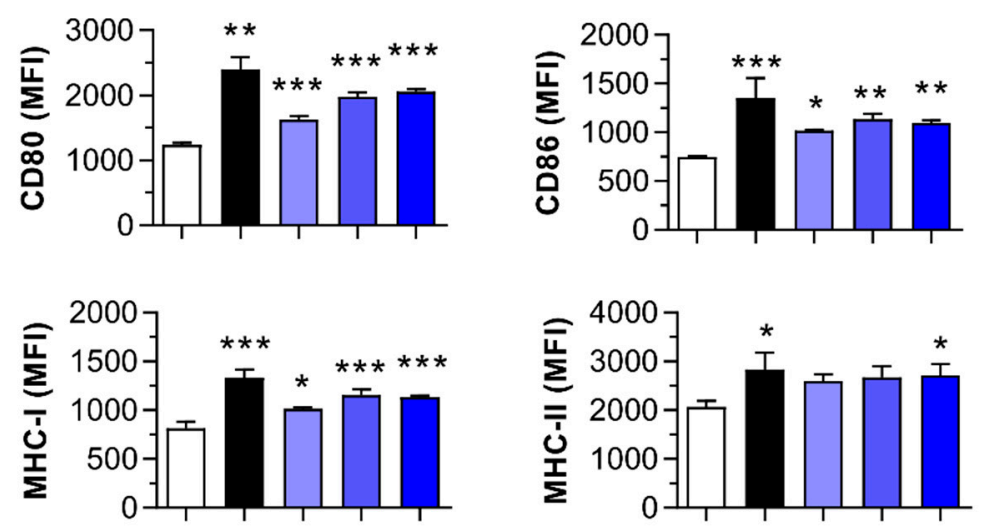

Figure 1. B. batryticatus protein extract (BBPE) induces bone marrow-derived dendritic cell (BMDC) maturation without cytotoxicity. BMDCs were treated with $\operatorname{BBPE}(10,50$, or $100 \mu \mathrm{g} / \mathrm{mL}$ ), lipopolysaccharide (LPS, $100 \mathrm{ng} / \mathrm{mL}$ ), or an equal volume of phosphate-buffered saline (PBS) as a control (Con) for $24 \mathrm{~h}$. Then, cell viability was measured using Ez-cytox cell viability assay kit (A) or annexin V/propidum iodide (PI) assay (B). BMDCs were stained with anti-CD11c, anti-CD80, anti-CD86, anti- MHC-I, and anti-MHC-II mAbs and analyzed to determine expression of surface molecules (C). Bar graphs represent the median fluorescence intensity (MFI) of each surface molecule in CD11c cells. All bar graphs show the mean $\pm \mathrm{SD}(n=3)$. Statistical analysis was performed using one-way ANOVA followed by Tukey's post hoc test. ${ }^{*} p<0.05$, ${ }^{* *} p<0.01$, and ${ }^{* * *} p<0.001$ represent significant differences. 
A

Con $\square$ LPS $\square$ BBPE $10 \mu \mathrm{g} / \mathrm{mL} \quad \square$ BBPE $50 \mu \mathrm{g} / \mathrm{mL} \quad \square$ BBPE $100 \mu \mathrm{g} / \mathrm{mL}$
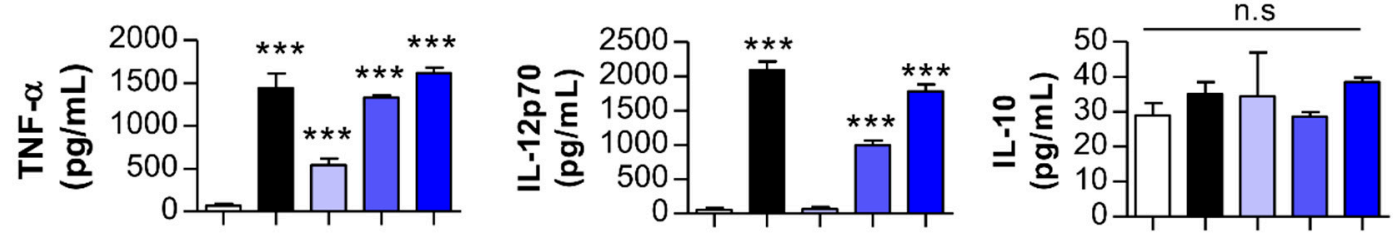

B
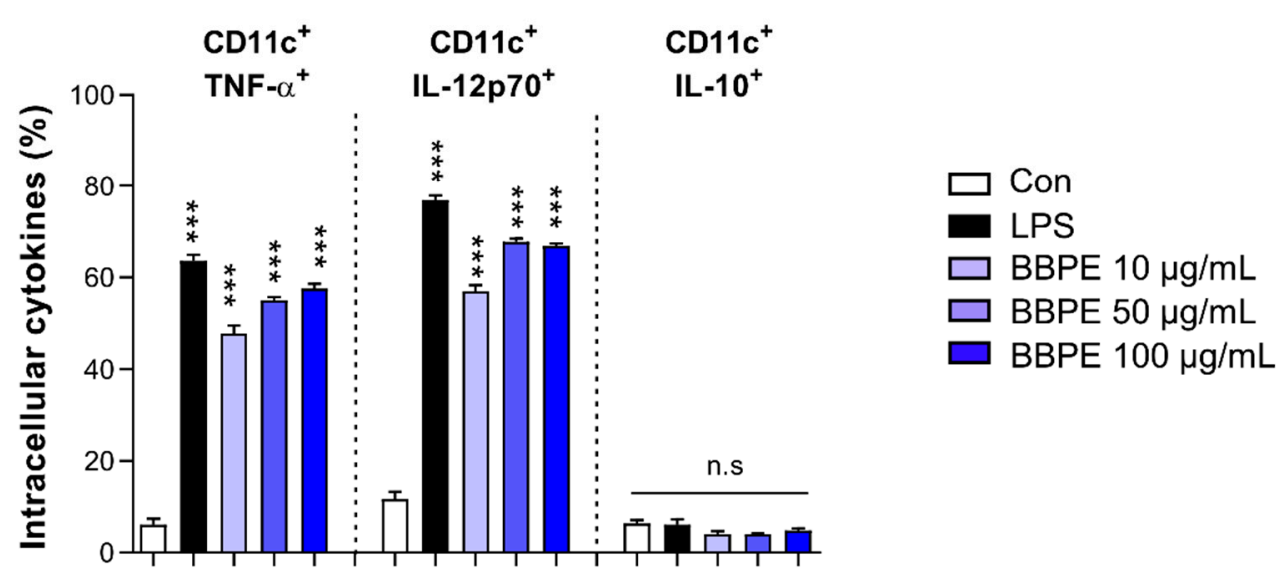

Figure 2. Th1-type cytokine production in BMDCs is increased by BBPE treatment. BMDCs were treated with BBPE (10, 50, or $100 \mu \mathrm{g} / \mathrm{mL}$ ), LPS (100 ng/mL), or PBS (Con) for $24 \mathrm{~h}$; then, TNF- $\alpha$, IL-12p70, and IL-10 levels in culture supernatant were measured by ELISA (A). Intracellular levels of TNF- $\alpha$, IL-12p70, and IL-10 in BMDCs were determined by flow cytometry (B). One representative plot of three independent experiments is shown. All bar graphs show the mean \pm SD $(n=3)$. Statistical analysis was performed using one-way ANOVA followed by Tukey's post hoc test. ${ }^{* * *} p<0.001$ represents significant differences.

A

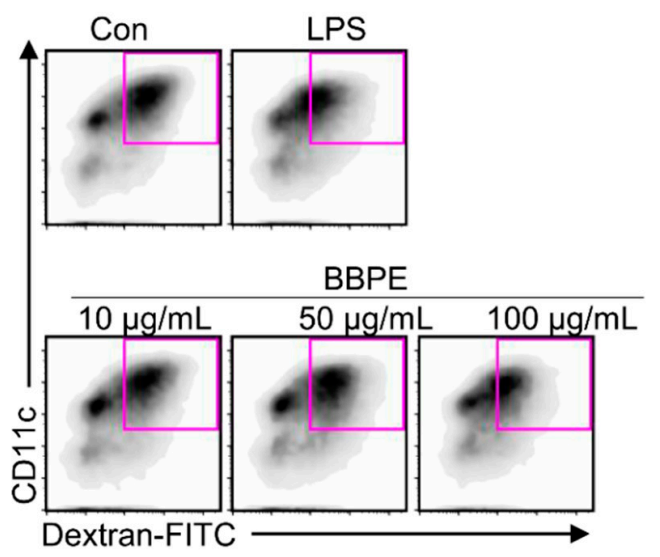

Figure 3. Cont.
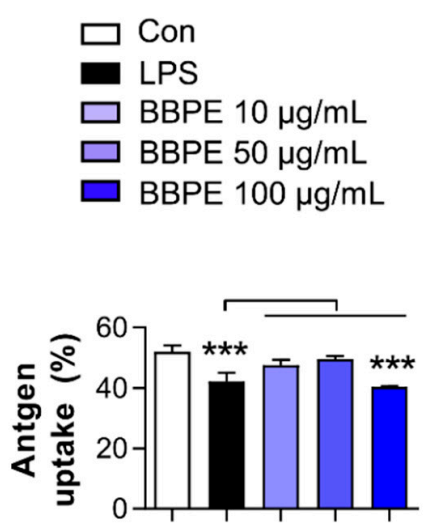
B

Gated on CD11c+
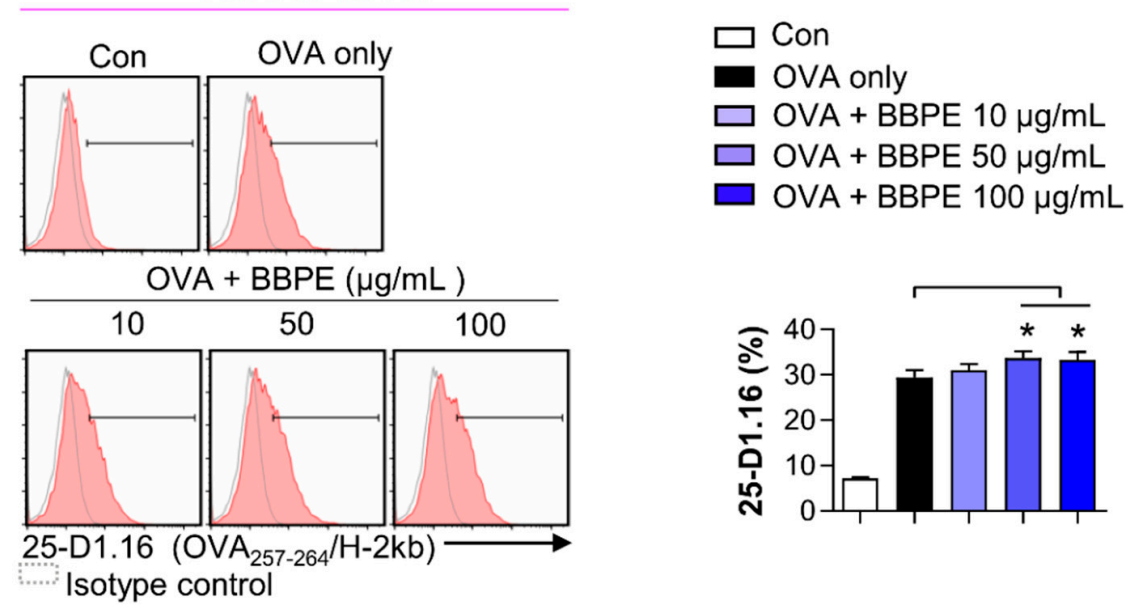

C

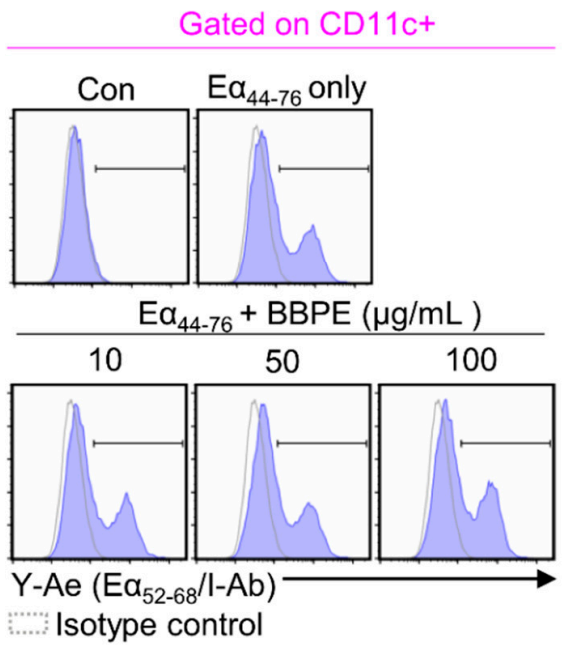

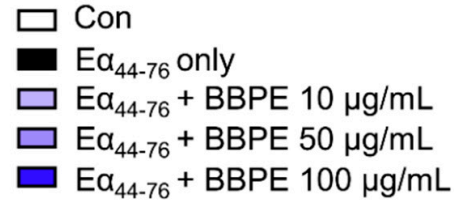

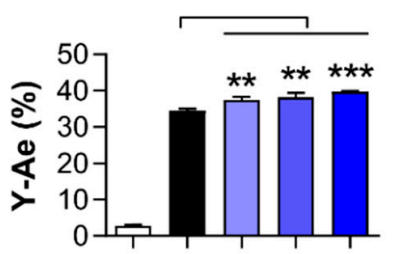

Figure 3. BBPE treatment alters endocytic activity and antigen-presenting ability in BMDCs. The endocytic capacity was assessed by flow cytometry (A). One representative plot of three independent experiments is shown. The bar graph represents the percentage of FITC-dextran and CD11c double-positive cells. The antigen-presenting ability of MHC class I (B) and MHC class II (C) was analyzed by flow cytometry. BMDCs were treated with ovalbumin (OVA) protein (500 $\mu \mathrm{g} / \mathrm{mL}$; B) or $\mathrm{E} \alpha_{44-76}$ peptide $(50 \mu \mathrm{g} / \mathrm{mL}$; C) in the presence or absence of BBPE (10, 50, or $100 \mu \mathrm{g} / \mathrm{mL})$ for $24 \mathrm{~h}$, and stained with anti-CD11c, anti-25-D1.16, or anti-Y-Ae mAbs. One representative histogram of three independent experiments is shown. The bar graphs represent the percentage of $\mathrm{OVA}_{257-264} / \mathrm{H}-2 \mathrm{~kb}(\mathbf{B})$ or $\mathrm{E} \alpha_{52-68} / \mathrm{I}-\mathrm{Ab}(\mathrm{C})$ in CD11c $\mathrm{C}^{+}$cells. All bar graphs show the mean $\pm \mathrm{SD}(n=3)$. Statistical analysis was performed using one-way ANOVA followed by Tukey's post hoc test. ${ }^{*} p<0.05,{ }^{* *} p<0.01$, and ${ }^{* *} p<0.001$ represent significant differences.

\subsection{BBPE-Treated BMDCs Induce T-Cell Proliferation and Activation}

We examined whether BMDCs matured by BBPE could increase T-cell proliferation and activation. Thus, carboxyfluorescein succinimidyl ester (CFSE)-labeled CD4 ${ }^{+}$or CD $8^{+}$ $\mathrm{T}$ cells were co-cultured with different groups of DCs prior to performing an allogenic in vitro $\mathrm{T}$ cell proliferation assay. As shown in Figure 4A, both CFSE-labeled CD4 ${ }^{+}$and $\mathrm{CD}^{+} \mathrm{T}$ cells co-cultured with BBPE-treated DCs showed higher proliferation than the same $\mathrm{T}$ cells co-cultured with nontreated DCs. In addition, $\mathrm{CD}^{+}$or $\mathrm{CD} 8^{+} \mathrm{T}$ cells co-cultured with BBPE-treated DCs produced higher levels of Th1 cytokines (interferon (IFN)- $\gamma$ and IL-2) than those co-cultured with immature DCs, while Th2 cytokines (IL-5) did not change in $\mathrm{CD}^{+} \mathrm{T}$ cells (Figure $4 \mathrm{~B}$ ). 
A

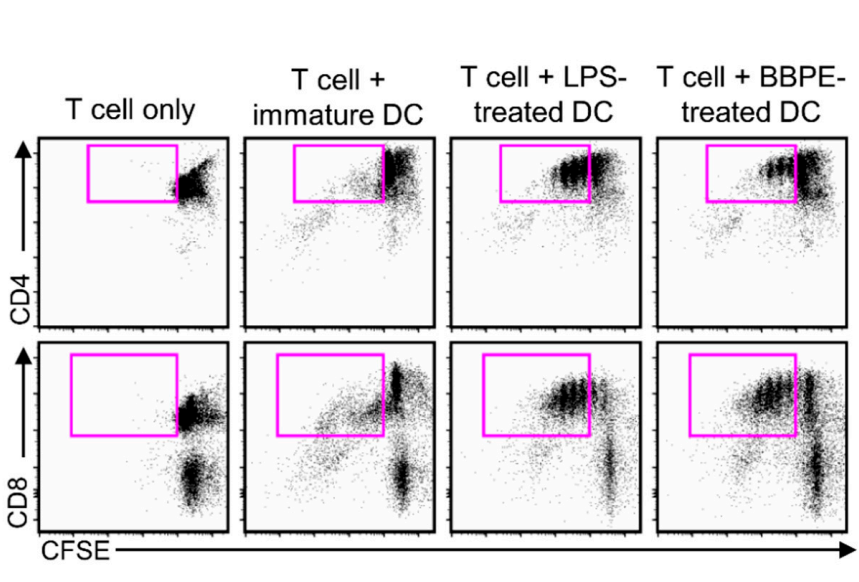

$\square$ T cell only

$\square T$ cell + immature DC

- $T$ cell + LPS-treated DC

$\square$ T cell + BBPE-treated DC

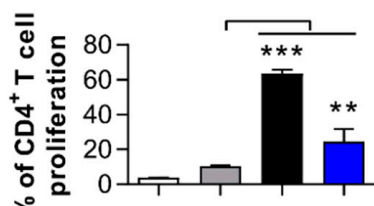

형

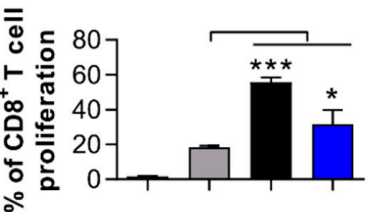

B

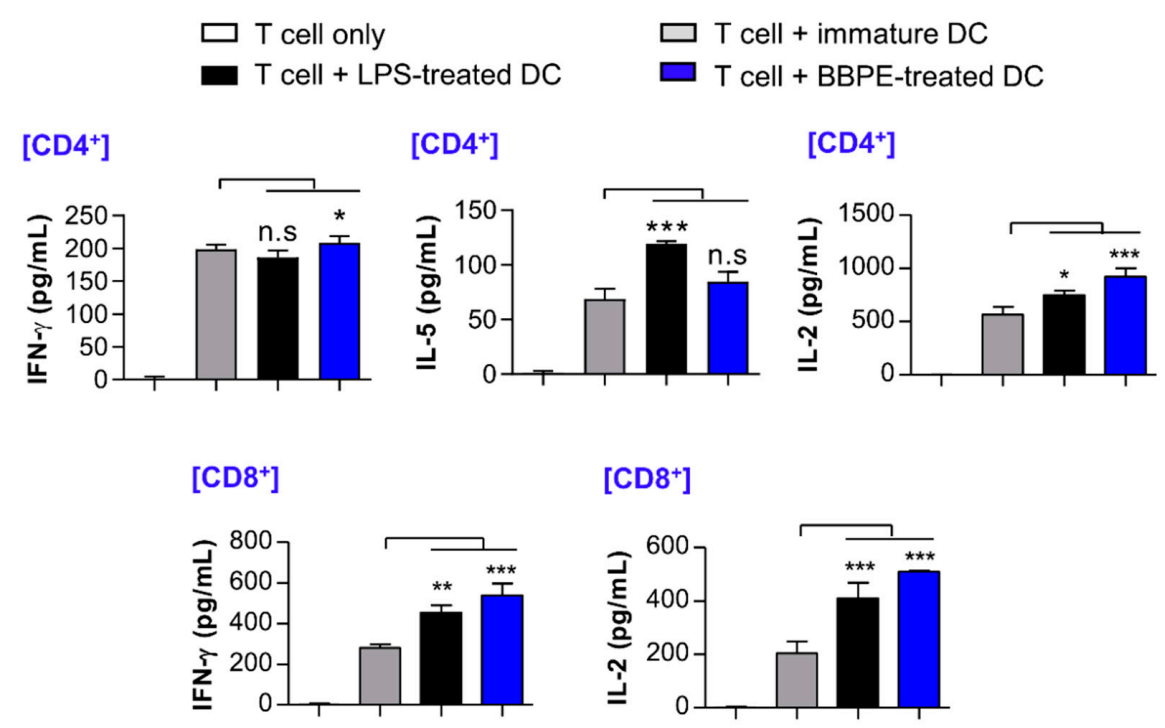

Figure 4. BBPE-treated BMDCs induce proliferation and activation of T cells. DCs were treated with BBPE $(100 \mu \mathrm{g} / \mathrm{mL})$ or LPS $(100 \mathrm{ng} / \mathrm{mL})$ for $24 \mathrm{~h}$, and then co-cultured with CFSE-labeled CD4 ${ }^{+}$or CD8 ${ }^{+} \mathrm{T}$ cells. After 2 days, cells were stained with anti-CD4 or anti-CD8 mAbs, and T-cell proliferation was analyzed by flow cytometry (A). IFN- $\gamma$, IL-5, and IL-2 levels in the culture supernatant were measured by ELISA (B). All bar graphs show the mean $\pm \operatorname{SD}(n=3)$. Statistical analysis was performed using one-way ANOVA followed by Tukey's post hoc test. ${ }^{*} p<0.05,{ }^{* *} p<0.01$, and ${ }^{* * *} p<0.001$ represent significant differences.

\subsection{BBPE Improves Antitumor Effects of DC Vaccine via Antigen-Specific Multifunctional T-Cell Activation}

A multifunctional T-cell response contributes to orchestrating strong anti-cancer immunity [27]. Therefore, to assess whether BBPE-treated DCs can induce antigen-specific multifunctional T-cell activity in OVA-pulsed DC-immunized mice, splenocytes isolated from each group (PBS, immature DC, OVA-pulsed DC, or OVA/BBPE-pulsed DC-injected) were re-stimulated with OVA peptide, and all possible combinations of three individual parameters (the production of IFN- $\gamma$, TNF- $\alpha$, and IL-2) and CD107a-producing cells were analyzed by flow cytometry. As shown in Figure 5A, the BBPE/OVA-pulsed DC-injected group showed a higher percentage of antigen-specific multifunctional (cells demonstrating $\geq 3$ functions; TNF- $\alpha^{+}$IL-2 ${ }^{+}$IFN- $\gamma^{+}$) CD4 ${ }^{+}$T-cell responses (Figure 5A). Additionally, the BBPE/OVA-pulsed DC-injected group showed the increased serum antigen-specific immunoglobulin G2c (IgG2c) response (Th1) without IgG1 response (Th2), which resulted in a higher ratio of IgG2c/IgG1 (Figure 5B). Furthermore, the BBPE/OVA-pulsed DC-injected 
group showed a higher percentage of antigen-specific multifunctional (TNF- $\alpha^{+} \mathrm{IL}-2^{+} \mathrm{IFN}-\gamma^{+}$, bifunctional (IL-2 $2^{+}$IFN- $\gamma^{+}$) CD8 ${ }^{+} \mathrm{T}$ cells as well as CD107a (cytotoxic granule)-producing $\mathrm{CD}^{+} \mathrm{T}$ cell, than OVA-pulsed DC-injected group (Figure 6A). Representative flow cytometry data showing multifunctional, bifunctional, and single-positive $\mathrm{T}$ cells are presented in Figure S1 (Supplementary Materials). Unstimulated control data are presented in Figure S2 (Supplementary Materials). Next, to investigate whether the multifunctional T-cell response induced by BBPE/OVA-pulsed DC immunization can protect against tumor progression, we established an E.G7-OVA intradermal tumor model. After three BBPE/OVA-pulsed DC injections, tumor growth was significantly lower $(27$ days, 30 days; $p<0.05)$ compared to injection with only OVA-pulsed DC (Figure 6B). Taken together, these results indicate that the BBPE/OVA-pulsed DC vaccine successfully induced and enhanced the Th1-type anti-tumor immunity in the E.G7-OVA intradermal model.

A

[CD4 ${ }^{+} \mathrm{T}$ cell population in OVA-restimulated cells]
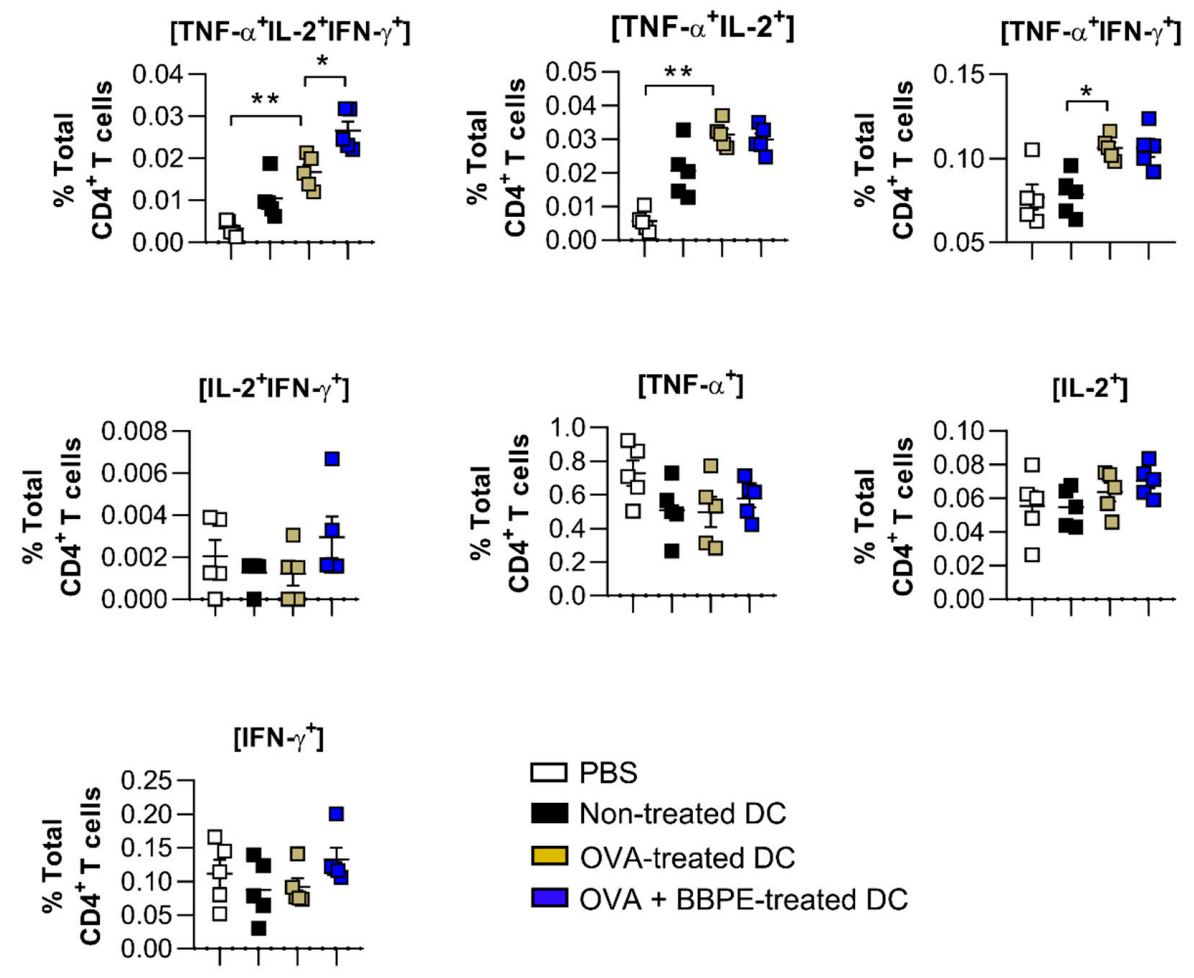

B

[IgG2c]

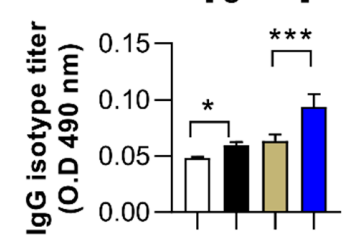

[IgG1]
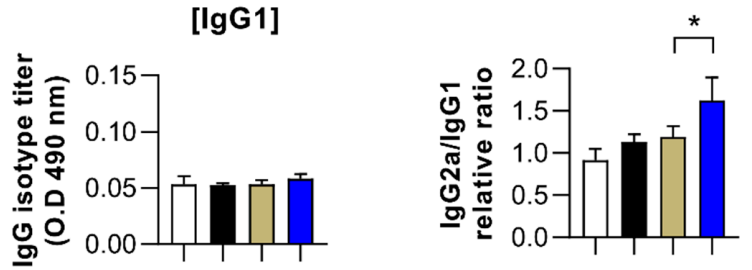

Figure 5. Administration of BBPE/OVA-treated DC vaccine enhances antigen-specific immune responses and antitumor effects. The mice were immunized with PBS, immature DCs, OVA-pulsed DCs, or OVA/BBPE-pulsed DCs ( $n=5$ mice/group). (A) After 2 weeks, multifunctional T cells were analyzed by flow cytometry. Each bar graph represents the percentage of antigen-specific multifunctional, bifunctional, or single-positive cells in $\mathrm{CD}^{+} \mathrm{CD}^{+} \mathrm{T}$ cells. (B) OVA $323-339$-specific IgG2C and IgG1 in serum were analyzed by ELISA. All experiments were repeated two times. All graphs show the mean \pm SD $(n=5)$ of a representative experiment. Statistical analysis was performed using one-way ANOVA followed by Tukey's post hoc test. ${ }^{*} p<0.05,{ }^{* *} p<0.01$ and ${ }^{* * *} p<0.001$ represent significant differences. 
A

CD8 $^{+} \mathrm{T}$ cell population in OVA-restimulated cells]
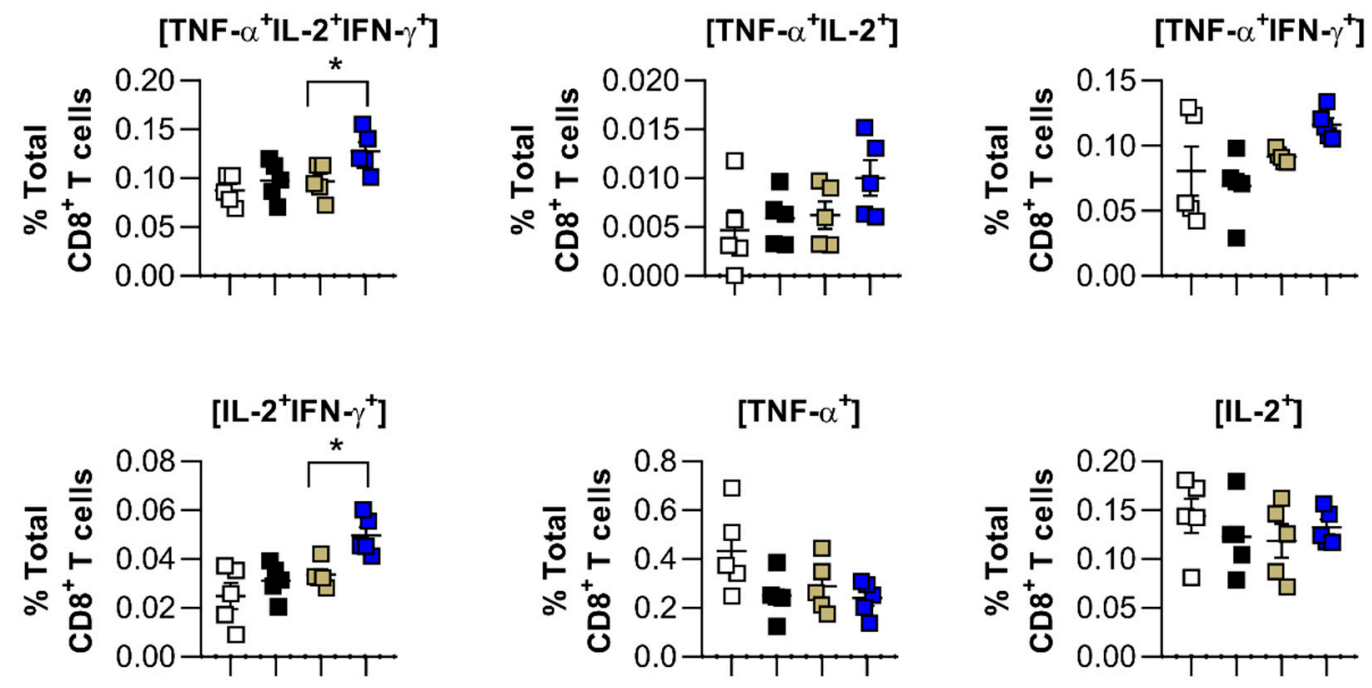

$\left[\mathrm{TNF}-\alpha^{+}\right]$

$\left[\mathrm{IL}^{+} \mathbf{2}^{+}\right]$
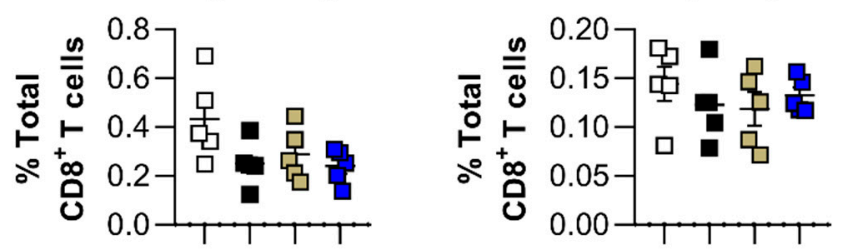

$\left[\mathrm{IFN}-\gamma^{+}\right]$
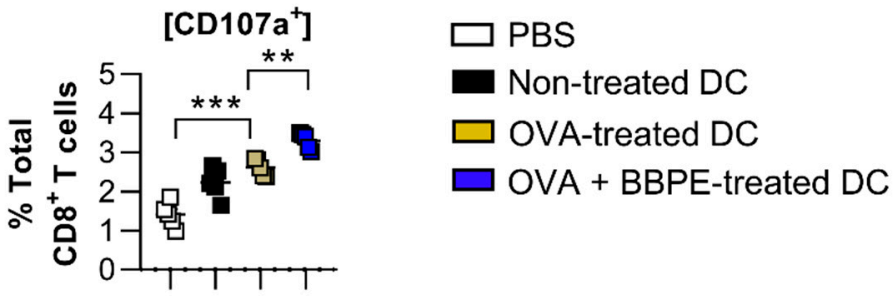

B

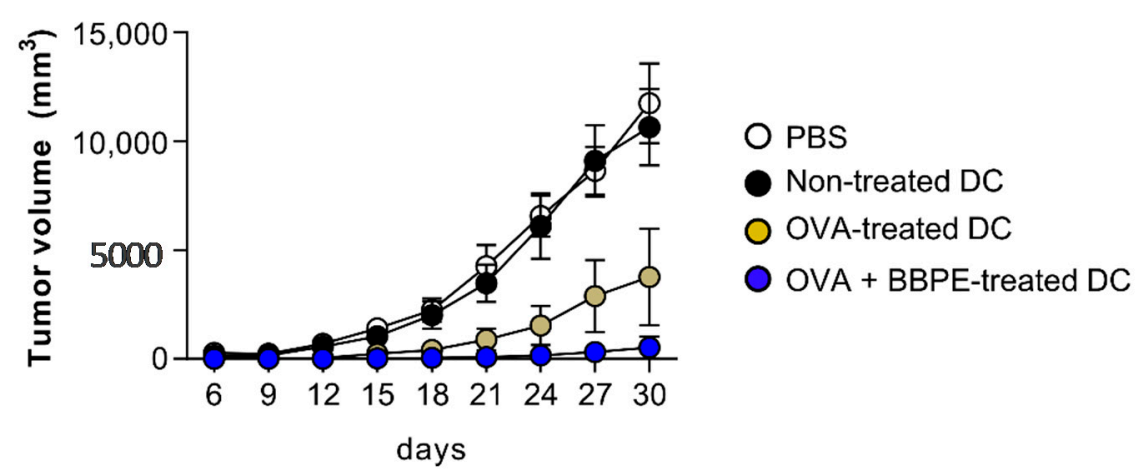

Figure 6. Administration of BBPE/OVA-treated DC vaccine enhances antigen-specific immune responses and anti-tumor effects. The mice were immunized with PBS, immature DCs, OVA-pulsed DCs, or OVA/BBPE-pulsed DCs ( $n=5$ mice/group). (A) After 2 weeks, multifunctional T cells were analyzed by flow cytometry. Each bar graph represents the percentage of antigen-specific multifunctional, bifunctional, or single-positive cells in $\mathrm{CD}^{+} \mathrm{CD} 8^{+} \mathrm{T}$ cells. (B) Mice were intradermally challenged with E.G7 $\left(2 \times 10^{6}\right.$ cells/mouse) and immunized with PBS or each DC group on day 1,3 , and 5 , and then the tumor growth was measured every 3 days ( $n=6$ mice/group). All experiments were repeated two times. All graphs show the mean \pm SD of a representative experiment. Statistical analysis was performed using one-way ANOVA followed by Tukey's post hoc test. ${ }^{*} p<0.05,{ }^{* *} p<0.01$, and ${ }^{* *} p<0.001$ represent significant differences. 


\section{Discussion}

In the current study, to investigate whether BBPE could act as an immune potentiator for the DC vaccine as an effective cancer immunotherapy, we firstly examined the immunological effects of BBPE on phenotypic and functional DC maturation.

DCs, the most powerful antigen-presenting cells (APCs), play pivotal roles in linking innate and adaptive immune response [28]. In their immature state, DCs have specific features, such as high capacity to capture antigens and low expression of co-stimulatory molecules and cytokines. Importantly, DCs activated by various stimuli migrate to lymph nodes and stimulate naïve T cells by expressing high levels of MHC class I/II and costimulatory molecules, and producing high amounts of cytokines [29]. Unfortunately, various factors generated by the tumor microenvironment (TME) hamper DC functions and Th1 polarization [30,31]. Therefore, phenotypic maturation of DCs into polarized Th1 is an effective strategy that can yield strong antitumor immunity by enhancing CTL activity, particularly compared to Th2 [32,33]. IL-12 is a key cytokine that enables polarization of $\mathrm{CD}^{+} \mathrm{T}$ cells into Th1, in addition to showing inherent antitumor effects [34,35]. Furthermore, the increased ability of DCs to cross-present tumor-associated antigens onto MHC class I is critical for the effective function of $\mathrm{CD}^{+} \mathrm{T}$ cells [36].

In the field of clinical nutrition, specific amino acids, such as glutamine, arginine, and branched-chain amino acids (valine, leucine, and isoleucine), are known to mainly regulate the innate immune system [37]. In particular, supplementation with branched-chain amino acids (BCAAs) efficiently leads to maturation and activation of dendritic cells [38,39]. In the present study, we first demonstrated that BBPE contains both essential and nonessential amino acids, including the balanced contents of branched-chain amino acids (Table 1). Subsequently, we found that treatment with BBPE leads to BMDC maturation, including increased co-stimulatory molecule levels, MHC class I and II expression (Figure 1), production of Th1 cytokines (Figure 2), and antigen-presenting ability to MHC class I and II (Figure 3). In this regard, a previous study revealed that the enriched contents of BCAAs in extracellular conditions induce maturation and Th1 polarization of DCs [39]. On this basis, we hypothesized that maturation and Th1 polarization in BMDCs by BBPE are related to the considerable contents of BCAAs in BBPE. Next, we showed that BBPEtreated DCs increased $\mathrm{CD} 4^{+}$and $\mathrm{CD} 8^{+} \mathrm{T}$-cell proliferation and activation (Figure 4). These findings demonstrate that BBPE induces Th1 polarization of BMDCs, as well as maturation. We speculated the protein-rich source in BBPE to be a valuable energy provider for DC maturation and Th1 polarization. Although we used BMDCs after CD11 $\mathrm{c}^{+}$selection in loosely adherent cell in all in vitro experiments, some macrophages also highly express CD11c [40]. Therefore, we assumed that BBPE can induce Th1 polarization in professional antigen-presenting cells, including macrophages and DCs.

T cells capable of simultaneously producing two (bifunctional) or three (multifunctional) cytokines, including IFN- $\gamma$, IL-2, and TNF- $\alpha$, have been recently shown to induce a powerful Th1-type immune response, which permits long-lasting antitumor immunity [41]. High-functional T cells producing both IFN- $\gamma$ and TNF- $\alpha$ can boost local effector cell production in local tissue, which importantly contributes to generating antitumor conditions [27]. Moreover, the high level of IL-2 is related to cytotoxic granules produced by $\mathrm{CTL}$, such as CD107a [42]. In this regard, multifunctional CD4 ${ }^{+} \mathrm{T}$ cells help to generate an antigen-specific antibody response, as well as $\mathrm{CD}^{+}$memory $\mathrm{T}$ cells $[43,44]$. CD4 ${ }^{+}$ $\mathrm{T}$ cells with cytotoxic activity also play an important role in anticancer immunity [45,46]. Therefore, induction of multifunctional $\mathrm{CD}^{+}$and $\mathrm{CD} 8^{+} \mathrm{T}$ cells is considered an effective strategy for orchestrating anticancer immunity. We used multiparameter flow cytometry to analyze $\mathrm{CD}^{+}$and $\mathrm{CD} 8^{+} \mathrm{T}$ cells in splenocytes after OVA-DC immunization. In our study, immunization with OVA/BBPE-treated DCs significantly increased the frequency of multifunctional or bifunctional $\mathrm{CD} 4^{+}$and $\mathrm{CD} 8^{+} \mathrm{T}$ cells in spleen. Furthermore, OVA/BBPE-treated DC-immunized mice exhibited an enhanced Th1-related antibody response (Figure 5). Collectively, the enhanced OVA-specific Th1-immune response medi- 
ated by OVA/BBPE-treated DC immunization resulted in a significant decrease in tumor volume in E.G7 tumor-bearing mice (Figure 6).

\section{Materials and Methods}

\subsection{Antibodies and Reagents}

Recombinant mouse granulocyte-macrophage colony stimulating factor (rmGM-CSF) and rm interleukin-4 (rmIL-4) were purchased from JW CreaGene (Daegu, Korea), whereas 2-mercaptoethanol (2-ME), 4-(2-hydroxyethyl)-1-piperazineethanesulfonic acid (HEPES), and nonessential amino acids were purchased from Invitrogen (Carlsbad, CA, USA). Roswell Park Memorial Institute (RPMI) 1640 medium, fetal bovine serum (FBS), and penicillin/streptomycin were purchased from Gibco (Grand Island, NY, USA). V450-conjugated anti-CD11c, anti-CD107a, V500-conjugated anti-CD8, BV510-conjugated live/dead staining kit, fluorescein isothiocyanate (FITC)-conjugated anti-CD80, anti-I-A-E $\alpha 52-68$, anti-CD4, anti-IL-10, dextran (40,000 Da), phycoerythrin (PE)-conjugated anti-CD86, anti-H-2kb (SIINFEKL), anti-IL-12p70, anti-IFN- $\gamma$, and allophycocyanin (APC)-conjugated anti-TNF- $\alpha$ were purchased from BD Biosciences (San Diego, CA, USA). APC-conjugated anti-MHC-I, APCCy7-conjugated anti-CD3, PerCP-Cy5.5-conjugated anti-CD8, and PE-Cy7-conjugated anti-IL2 and anti-MHC-II were purchased from eBioscience (San Diego, CA, USA). Lipopolysaccharide (LPS) from Escherichia coli O111:B4 was purchased from InvivoGen (San Diego, CA, USA).

\subsection{Preparation of B. batryticatus Proteins Extract}

B. batryticatus proteins were extracted following the method from Yi et al. [47] with slight modification. First, $100 \mathrm{~g}$ of B. batryticatus were blended with $600 \mathrm{~mL}$ of cold water containing $0.16 \%$ ascorbic acid for $1 \mathrm{~min}$ using a blender. Then, the obtained insect suspension was sieved through a stainless-steel filter with a pore size of $125 \mu \mathrm{m}$. The filtrates were centrifuged at $15,000 \times \mathrm{g}$ for $30 \mathrm{~min}$ at $4{ }^{\circ} \mathrm{C}$. From top to bottom, the obtained fractions contained the lipid layer, the supernatant, and the pellet. The thin lipid layer was removed, and the supernatant fraction was collected and freeze-dried. The freeze-dried supernatant (thereafter called B. batryticatus protein extract, BBPE) was stored at $-20^{\circ} \mathrm{C}$. The yield of the powder extract was $14.93 \%$. After then, the BBPE was resuspended in phosphate-buffered saline (PBS) and filtered using a $0.22 \mu \mathrm{m}$ syringe filter (Corning, NY, USA). Next, the absence of endotoxin or LPS contamination in BBPE was confirmed using the Limulus Amebocyte Lysate (LAL) assay kit (Lonza, Basel, Switerland) following the manufacturer's instruction. The content of endotoxin in BBPE was $<4 \mathrm{pg} / \mathrm{mL}(0.1 \mathrm{EU} / \mathrm{mL})$.

\subsection{Analysis of Amino-Acid Composition}

The amino-acid composition of BBPE was measured according to the method described by Bidlingmeyer et al. [48] with slight modification. The BBPE sample was hydrolyzed using $6 \mathrm{M} \mathrm{HCl}$ and $1 \%$ phenol solution. Hydrolyzed BBPE was taken for precolumn derivatization using phenyl isothiocyanate (PITC). Briefly, $40 \mu \mathrm{L}$ of hydrolyzed BBPE was mixed with a distilled water (DW)/trethylamine/PITC/MeOH (1:1:1:7) solution for $30 \mathrm{~min}$ and dried. The sample was re-dissolved in solvent A ( $140 \mathrm{mM}$ sodium acetate containing $6 \%$ acetonitrile) and filtered using a $0.22 \mu \mathrm{m}$ filter. Analysis was performed with a Waters 510 HPLC pump using a Waters Pico-tag column $(3.9 \times 300 \mathrm{~mm}, 4 \mu \mathrm{m})$. HPLC spectra were detected at $254 \mathrm{~nm}$. The separation was performed by the following gradient program: 0 min ( $0 \%$ solvent B), 9 min (14\% B), $9.2 \mathrm{~min}(20 \% \mathrm{~B}), 17.5 \mathrm{~min}(46 \% \mathrm{~B}), 17.7 \mathrm{~min}$ $(100 \% \mathrm{~B})$, and $21 \mathrm{~min}(0 \% \mathrm{~B}) ; 60 \%$ acetonitrile was used as solvent $\mathrm{B}$.

\subsection{Cells and Animals}

Specific pathogen-free, 6-8 week old female C57BL/ 6 or BALB/c mice were purchased from Orient Bio, Inc. (Seoul, Korea). All procedures were approved by the Institutional Animal Care and Use Committee of Korea Atomic Energy Research Institute (KAERIIACUC-2019-001). 
Bone marrow-derived dendritic cells (BMDCs) were generated from C57BL/6 mice according to established protocols [49]. Briefly, red blood cells (RBCs) in the whole bone marrow cells were lysed using RBC lysis buffer. Then, $10 \mathrm{~mL}$ of RPMI 1640 medium supplemented with $10 \%$ FBS, $100 \mathrm{U} / \mathrm{mL}$ of penicillin/streptomycin, $20 \mathrm{ng} / \mathrm{mL}$ of GMCSF, $0.5 \mathrm{ng} / \mathrm{mL}$ of IL-4, $50 \mu \mathrm{M}$ 2-mercaptoethanol, $1 \%$ minimum essential media (MEM) nonessential amino acids, and $5 \mathrm{mM}$ HEPES buffer (DC culture medium) was added to $1 \times 10^{6}$ cells per $100 \mathrm{~mm}$ plate. Next, $10 \mathrm{~mL}$ of DC culture medium was added on days 3 and 6 of culture. On day 8, BMDCs were isolated by positive selection using anti-CD11c microbeads (Miltenyi Biotec, Bergisch Gladbach, Germany) in loosely adherent cells.

E.G7 cells, which express ovalbumin (OVA) and are derived from EL4 (thymoma), were purchased from American Type Culture Collection (VA, USA). E.G7 cells were cultured in RPMI 1640 medium supplemented with $2 \mathrm{mM}$ L-glutamine, $4.5 \mathrm{~g} / \mathrm{L}$ glucose, $10 \mathrm{mM}$ HEPES, $1.0 \mathrm{mM}$ sodium pyruvate, $0.05 \mathrm{mM} 2-\mathrm{ME}, 0.4 \mathrm{mg} / \mathrm{mL}$ G418, $1.5 \mathrm{~g} / \mathrm{L}$ sodium bicarbonate, $10 \% \mathrm{FBS}$, and $100 \mathrm{U} / \mathrm{mL}$ of penicillin/streptomycin. BMDCs and E.G7 were cultured at $37^{\circ} \mathrm{C}$ in humidified atmosphere containing $5 \% \mathrm{CO}_{2}$.

\subsection{Measurement of Cell Viability}

Cell viability was determined using the Ez-cytox cell viability (Daeil Lab Service, Seoul, Korea) and Annexin V/propidium iodide (PI) apoptosis detection kit (BD Biosciences). BMDCs were seeded into a 48 -well plate $\left(0.25 \times 10^{6}\right.$ cells /well $)$ and treated with LPS $(100 \mathrm{ng} / \mathrm{mL})$ or BBPE $(1,10,50$, or $100 \mu \mathrm{g} / \mathrm{mL})$ for $24 \mathrm{~h}$. Cells treated with PBS were used as a negative control. Cells treated with LPS were used as a positive control. Subsequently, the medium was replaced with $10 \%$ Ez-cytox solution for $1 \mathrm{~h}$. The absorbance was measured at $450 \mathrm{~nm}$ using a microplate reader (TECAN, Salzburg, Austria). For the annexin V/PI assay, the cells were harvested and washed with PBS and then stained with FITC-annexin V and PI following a previously described method [50]. Cytotoxicity was evaluated by flow cytometry (MACSQuant VYB, Miltenyi Biotec) and analyzed using FlowJo version 10 (TreeStar, Ashland, OR, USA).

\subsection{Analysis of Surface Molecule Expression in BMDCs}

To evaluate the effects of BBPE on DC maturation, cells were stained with specifically labeled fluorescent-conjugated mAbs for $20 \mathrm{~min}$ at $25^{\circ} \mathrm{C}$ to detect expression of CD80, CD86, MHC class I, and MHC class II in CD11c-positive cells, as previously described [51]. The expression of surface molecules was detected by flow cytometry. LPS $(100 \mathrm{ng} / \mathrm{mL})$ was used as a positive control for DC maturation.

\subsection{Analysis of Cytokines in BMDCs}

The levels of TNF- $\alpha$, IL-12p70, and IL-10 in the cell culture supernatant were measured using commercial enzyme-linked immunosorbent assay (ELISA) kits according to the manufacturer's instructions (eBioscience).

For intracellular cytokine staining, BMDCs were treated with BBPE or LPS for $12 \mathrm{~h}$ in the presence of $1 \mu \mathrm{g} / \mathrm{mL}$ of brefeldin A (GolgiPlugTM, BD Bioscience). The cells were stained with PE-Cy7-conjugated CD11c mAb and the BV510-conjugated live/dead cell staining kit for $20 \mathrm{~min}$ at $25^{\circ} \mathrm{C}$. Then, the cells were fixed and permeabilized using a Cytofix/Cytoperm kit following the manufacturer's instructions (BD Bioscience) and stained with APC-conjugated anti-TNF- $\alpha$, PE-conjugated IL-12p70, and FITC-conjugated IL-10 mAbs. The intracellular levels of TNF- $\alpha$, IL-12p70, and IL-10 in CD11c-positive cells were detected by flow cytometry [52].

\subsection{Analysis of Antigen Uptake}

After incubation of BMDCs with BBPE or LPS for $24 \mathrm{~h}$, the cells were pulsed with FITC-conjugated dextran $(0.5 \mathrm{mg} / \mathrm{mL})$ for $30 \mathrm{~min}$ at $37^{\circ} \mathrm{C}$. The cells were washed with ice-cold PBS three times to stop the reaction and stained with anti-CD11c. The data were collected by flow cytometry. 


\subsection{Analysis of Antigen-Presenting Ability}

The BMDCs were stimulated with $500 \mu \mathrm{g} / \mathrm{mL}$ of OVA protein (Sigma-Aldrich, St. Louis, MO, USA) or $25 \mu \mathrm{g} / \mathrm{mL}$ of $E \alpha_{44-76}$ peptide (RLEEFAKFASFEAQGALANIAVDKANLDVMKKR; underlined sequence binds to MHC-II) in the absence or presence of BBPE for $24 \mathrm{~h}$. To investigate peptide formation of MHC-I or MHC-II, the cells were stained with anti$\mathrm{CD} 11 \mathrm{c}$, anti-H-2kb (SIINFEKL, eBioscience) or anti-I-Ab-E $\alpha_{52-68}$ (Y-Ae; ASFEAQGALANIAVDKA, eBioscience) $\mathrm{mAbs}$ for $20 \mathrm{~min}$ at $25^{\circ} \mathrm{C}$. Data were collected by flow cytometry [52].

\subsection{Mixed Lymphocyte Reaction (MLR) Assay}

To determine the T-cell proliferative ability of BBPE-treated BMDCs, splenocytes were isolated from spleen of BALB/c mice. After RBC lysis, splenocytes were incubated with anti-CD4- or anti-CD8-coated magnetic microbeads (Miltenyi Biotec), and the microbeadconjugated $\mathrm{CD}^{+}$and $\mathrm{CD}^{+}$cells were separated using an LS column (Miltenyi Biotec) according to the manufacturer's instructions. These separated cells were stained with $1 \mu \mathrm{M}$ CSFE for $20 \mathrm{~min}$ at $37^{\circ} \mathrm{C}$ and washed with $2 \%$ FBS in PBS for $10 \mathrm{~min}$. The BMDCs $\left(0.2 \times 10^{5}\right.$ cells $)$ treated with BBPE or LPS for $24 \mathrm{~h}$ were co-cultured with CFSE-stained $\mathrm{CD}^{+}$and $\mathrm{CD} 8^{+} \mathrm{T}$ cells $\left(1 \times 10^{5}\right.$ cells $)$ in a 96-well U-bottom plate in the presence of $1 \mu \mathrm{g} / \mathrm{mL}$ of plate-bound anti-CD3 and $1 \mu \mathrm{g} / \mathrm{mL}$ of soluble anti-CD28 mAb (eBioscience). After 2 days of co-culture, the T cells were stained with fluorescent conjugated anti-CD4 or anti-CD8 $\mathrm{mAb}$ for $20 \mathrm{~min}$ and analyzed by flow cytometry. The levels of IFN- $\gamma$, IL-5, and IL-2 in cell culture supernatant was measured by ELISA.

\subsection{Mouse Immunization}

To investigate the immune-enhancing capacity of BBPE in DC vaccine mice, the animals were divided into four groups ( $n=5$ per group): (1) PBS, (2) immature DCs, (3) OVA ( $5 \mu \mathrm{g} / \mathrm{mL}$ of $\mathrm{OVA}_{257-264}$ and $5 \mu \mathrm{g} / \mathrm{mL}$ of $\mathrm{OVA}_{323-339)}$-pulsed DC, and (4) OVA and $100 \mu \mathrm{g} / \mathrm{mL}$ of BBPE-pulsed DC. The mice of each group were injected intravenously with PBS or each group of DCs $(0.1 \mathrm{~mL} /$ mouse) on days 1,3 , and 5 .

\subsection{Analysis of Multifunctional T-Cell Subsets in Spleens of Immunized Mice}

Two weeks after the last immunization, spleen cells were isolated from each group of mice and lysed with RBC lysis buffer. Next, the cells were re-stimulated with $\mathrm{OVA}_{257-264}$ and $\mathrm{OVA}_{323-339}$ in the presence of GolgiPlug $(0.5 \mu \mathrm{g} / \mathrm{mL})$, GolgiStop $(0.5 \mu \mathrm{g} / \mathrm{mL})$, and anti-CD107a antibody $\left(2.5 \mu \mathrm{g} / \mathrm{mL}\right.$, BD Bioscience) for $6 \mathrm{~h}$ at $37^{\circ} \mathrm{C}$. Subsequently, the cells were stained with a live/dead cell staining kit, APC-Cy7-conjugated anti-CD3, and V500-conjugated anti-CD8 $\mathrm{mAbs}$ for $30 \mathrm{~min}$ at $4{ }^{\circ} \mathrm{C}$. After the fixation and permeabilization step, according to the manufacturer's instructions, cells were stained with PE-conjugated anti-IFN- $\gamma$, APC-conjugated anti-TNF- $\alpha$, and PE-Cy7-conjugated IL-2 mAbs for $30 \mathrm{~min}$ at $4{ }^{\circ} \mathrm{C}$. The cells were analyzed using flow cytometry and FlowJo software (BD Bioscience). The intracellular levels of TNF- $\alpha$, IL-12p70, and IL-10 in CD11c-positive cells were detected by flow cytometry [53].

\subsection{Measurement of OVA-Specific Antibody}

OVA-specific IgG1 (Sigma-Aldrich) and IgG2a (Southern Biotech, Birmingham, AL, USA) antibodies in serum were measured by the indirect ELISA. In brief, plates were coated with $\mathrm{OVA}_{323-339}$ peptide $(1 \mu \mathrm{g} / \mathrm{mL})$ and incubated overnight at $4{ }^{\circ} \mathrm{C}$. The wells were washed three times with PBS containing 0.05\% ( $v / v)$ Tween-20 (PBS/Tween) and then blocked with PBS containing $5 \% \mathrm{FBS}$ at $37^{\circ} \mathrm{C}$ for $2 \mathrm{~h}$. After washing three times with PBS, sera obtained from each immunized mouse were added (dilution 1:500), and the plates were incubated for $2 \mathrm{~h}$ at $37^{\circ} \mathrm{C}$ followed by washing three times with PBS. Then, horseradish peroxidase (HRP)-conjugated secondary antibodies against IgG1 and IgG2a were added, and the plates were incubated for $1 \mathrm{~h}$ at RT. The reaction was developed using $3,3^{\prime}, 5,5^{\prime \prime}$-tetramethylbenzidine (TMB) substrate (Sigma-Aldrich), and the enzyme reaction 
was terminated by adding $2 \mathrm{~N} \mathrm{H}_{2} \mathrm{SO}_{4}$. The optical density was detected at $495 \mathrm{~nm}$ within 20 min using a microplate ELISA reader [53].

\subsection{Tumor Challenge}

Mice were injected intradermally into the right lower back with E.G7 cells $\left(2 \times 10^{6}\right.$ cells $/$ mice). PBS, immature DCs (iDCs), DCs pulsed with $\mathrm{OVA}_{257-264}$ and $\mathrm{OVA}_{323-339}$ (OVA-DCs), or BBPE-treated DCs pulsed with $\mathrm{OVA}_{257-264}$ and $\mathrm{OVA}_{323-339}$ (BBPE/OVA-DCs) were intravenously injected on days 1,3, and 5 after tumor implantation. Tumor size was measured every 3 days, and tumor volume was calculated as follows:

$$
\mathrm{V}=(2 \mathrm{~A} \times \mathrm{B}) / 2,
$$

where $\mathrm{A}$ is the length of the short axis and $\mathrm{B}$ is the length of the long axis.

\subsection{Statistical Analysis}

All analyses were repeated at least three times with consistent results. The significance for comparisons between samples was determined by one-way ANOVA followed by Tukey's multiple comparison test or unpaired $t$-tests using statistical software (GraphPad Prism version 5, GraphPad Prism Software, San Diego, CA, USA).

\section{Conclusions}

In the present study, our goal was to evaluate BBPE as an immune potentiator to increase the efficacy of the DC vaccine for cancer immunotherapy. BBPE is mainly composed of 18 amino acids with nine essential ones. BBPE induces BMDC maturation and activation, and it inhibits OVA-expressing tumor growth via enhancing the OVA-specific Th1-immune response in DC vaccine mice. Our results demonstrated that BBPE will be an interesting and effective immune potentiator for the DC-based vaccine for cancer therapy. However, further studies regarding the correlation between the quality control of B. batryticatus and nutritional and physiological change are needed for the general use of BBPE as a vaccine adjuvant.

Supplementary Materials: The following are available online. Figure S1: Example gating strategies for flow cytometry analysis for multifunctional T cells. Figure S2: Percentage of multi-bifunctional, or each single cytokine production in unstiumulated cells gated on $\mathrm{CD}^{+} \mathrm{CD}^{+}{ }^{+}$or $\mathrm{CD}^{+} \mathrm{CD}^{+}$cells.

Author Contributions: Conceptualization, E.-B.B.; methodology, W.S.K.; validation, H.-Y.S. and J.M.H.; investigation, H.-Y.S., J.M.H., and W.S.K.; resources, E.-H.B.; writing-original draft preparation, H.-Y.S. and J.M.H.; writing-review and editing, H.-Y.S.; funding acquisition, H.S.S., supervision, E.-B.B. All authors have read and agreed to the published version of the manuscript.

Funding: This research was funded by the Basic Science Research Program through the National Research Foundation of Korea (NRF) under grant NRF-2019R1C1C1002484 and the Nuclear R\&D Program of Ministry of Science and ICT.

Institutional Review Board Statement: This study was approved by the Institutional Animal Care and Use Committee of Korea Atomic Energy Research Institute (KAERI-IACUC-2019-001).

Informed Consent Statement: Not applicable.

Data Availability Statement: Data is contained with the article or supplementary materials.

Conflicts of Interest: The authors declare no conflict of interest.

Sample Availability: Not available.

\section{References}

1. Dimberu, P.M.; Leonhardt, R.M. Cancer immunotherapy takes a multi-faceted approach to kick the immune system into gear. Yale J. Biol. Med. 2011, 84, 371-380. [PubMed]

2. Shore, N.D. Advances in the understanding of cancer immunotherapy. BJU Int. 2015, 116, 321-329. [CrossRef] [PubMed] 
3. Yang, Y. Cancer immunotherapy: Harnessing the immune system to battle cancer. J. Clin. Investig. 2015, 125, 3335-3337. [CrossRef] [PubMed]

4. Voena, C.; Chiarle, R. Advances in cancer immunology and cancer immunotherapy. Discov. Med. 2016, 21, 125-133. [PubMed]

5. Guo, C.; Manjili, M.H.; Subjeck, J.R.; Sarkar, D.; Fisher, P.B.; Wang, X.Y. Therapeutic cancer vaccines: Past, present, and future. Adv. Cancer Res. 2013, 119, 421-475. [CrossRef]

6. Pyzer, A.R.; Avigan, D.E.; Rosenblatt, J. Clinical trials of dendritic cell-based cancer vaccines in hematologic malignancies. Hum. Vaccines Immunother. 2014, 10, 3125-3131. [CrossRef]

7. Santos, P.M.; Butterfield, L.H. Dendritic cell-based cancer vaccines. J. Immunol. 2018, 200, 443-449. [CrossRef]

8. Sabado, R.L.; Balan, S.; Bhardwaj, N. Dendritic cell-based immunotherapy. Cell Res. 2017, 27, 74-95. [CrossRef]

9. Palucka, K.; Banchereau, J. Dendritic-cell-based therapeutic cancer vaccines. Immunity 2013, 39, 38-48. [CrossRef]

10. Bowen, W.S.; Svrivastava, A.K.; Batra, L.; Barsoumian, H.; Shirwan, H. Current challenges for cancer vaccine adjuvant development. Expert Rev. Vaccines 2018, 17, 207-215. [CrossRef]

11. Reed, S.G.; Orr, M.T.; Fox, C.B. Key roles of adjuvants in modern vaccines. Nat. Med. 2013, 19, 1597-1608. [CrossRef] [PubMed]

12. Apostolico Jde, S.; Lunardelli, V.A.; Coirada, F.C.; Boscardin, S.B.; Rosa, D.S. Adjuvants: Classification, modus operandi, and licensing. J. Immunol. Res. 2016, 2016. [CrossRef] [PubMed]

13. Ho, N.I.; Huis In 't Veld, L.G.M.; Raaijmakers, T.K.; Adema, G.J. Adjuvants enhancing cross-presentation by dendritic cells: The key to more effective vaccines? Front. Immunol. 2018, 9, 2874. [CrossRef] [PubMed]

14. Petrovsky, N. Comparative safety of vaccine adjuvants: A summary of current evidence and future needs. Drug Saf. 2015, 38, 1059-1074. [CrossRef] [PubMed]

15. Ragupathi, G.; Yeung, K.S.; Leung, P.C.; Lee, M.; Lau, C.B.; Vickers, A.; Hood, C.; Deng, G.; Cheung, N.K.; Cassileth, B.; et al. Evaluation of widely consumed botanicals as immunological adjuvants. Vaccine 2008, 26, 4860-4865. [CrossRef]

16. Kim, T.K.; Yong, H.I.; Kim, Y.B.; Kim, H.W.; Choi, Y.S. Edible insects as a protein source: A review of public perception, processing technology, and research trends. Food Sci. Anim. Resour. 2019, 39, 521-540. [CrossRef]

17. Jiang, X.; Zhang, Z.; Chen, Y.; Cui, Z.; Shi, L. Structural elucidation and in vitro antitumor activity of a novel oligosaccharide from Bombyx batryticatus. Carbohydr. Polym. 2014, 103, 434-441. [CrossRef]

18. Wu, J.Y.; Sheikho, A.; Ma, H.; Li, T.C.; Zhao, Y.Q.; Zhang, Y.L.; Wang, D. Molecular mechanisms of Bombyx batryticatus ethanol extract inducing gastric cancer SGC-7901 cells apoptosis. Cytotechnology 2017, 69, 875-883. [CrossRef]

19. He, L.Y.; Hu, M.B.; Li, R.L.; Zhao, R.; Fan, L.H.; Wang, L.; Peng, W.; Liu, Y.J.; Wu, C.J. The effect of protein-rich extract from bombyx batryticatus against glutamate-damaged PC12 cells via regulating gamma-aminobutyric acid signaling pathway. Molecules $\mathbf{2 0 2 0}$ 25, 553. [CrossRef]

20. Hu, M.; Liu, Y.; He, L.; Yuan, X.; Peng, W.; Wu, C. Antiepileptic effects of protein-rich extract from bombyx batryticatus on mice and its protective effects against H2O2-induced oxidative damage in PC12 cells via Regulating PI3K/Akt signaling pathways. Oxid. Med. Cell Longev. 2019, 2019. [CrossRef]

21. Wu, W.P.; Cao, J.; Wu, J.Y.; Chen, H.; Wang, D. Anticancer activity of Bombyx batryticatus ethanol extract against the human tumor cell line HeLa. Genet. Mol. Res. 2015, 14, 79-88. [CrossRef] [PubMed]

22. Yuan, L.; Bing, Z.; Han, J.; An, X.; Liu, X.; Li, R.; Wang, C.; Sun, X.; Yang, L.; Yang, K. Study on the anti-tumor mechanism related to immune microenvironment of Bombyx Batryticatus on viral and non-viral infections of hepatocellular carcinoma. Biomed. Pharmacother. 2020, 124. [CrossRef] [PubMed]

23. Hu, M.; Yu, Z.; Wang, J.; Fan, W.; Liu, Y.; Li, J.; Xiao, H.; Li, Y.; Peng, W.; Wu, C. Traditional uses, origins, chemistry and pharmacology of bombyx batryticatus: A review. Molecules 2017, 22, 1779. [CrossRef] [PubMed]

24. Daly, J.M.; Reynolds, J.; Sigal, R.K.; Shou, J.; Liberman, M.D. Effect of dietary protein and amino acids on immune function. Crit. Care Med. 1990, 18, S86-S93. [CrossRef]

25. Banchereau, J.; Briere, F.; Caux, C.; Davoust, J.; Lebecque, S.; Liu, Y.J.; Pulendran, B.; Palucka, K. Immunobiology of dendritic cells. Annu. Rev. Immunol. 2000, 18, 767-811. [CrossRef]

26. Alloatti, A.; Kotsias, F.; Magalhaes, J.G.; Amigorena, S. Dendritic cell maturation and cross-presentation: Timing matters! Immunol. Rev. 2016, 272, 97-108. [CrossRef]

27. Ma, C.; Cheung, A.F.; Chodon, T.; Koya, R.C.; Wu, Z.; Ng, C.; Avramis, E.; Cochran, A.J.; Witte, O.N.; Baltimore, D.; et al. Multifunctional T-cell analyses to study response and progression in adoptive cell transfer immunotherapy. Cancer Discov. 2013, 3, 418-429. [CrossRef]

28. Banchereau, J.; Steinman, R.M. Dendritic cells and the control of immunity. Nature 1998, 392, 245-252. [CrossRef]

29. Veglia, F.; Gabrilovich, D.I. Dendritic cells in cancer: The role revisited. Curr. Opin. Immunol. 2017, 45, 43-51. [CrossRef]

30. Ma, Y.; Shurin, G.V.; Peiyuan, Z.; Shurin, M.R. Dendritic cells in the cancer microenvironment. J. Cancer 2013, 4, 36-44. [CrossRef]

31. Lee, J.H.; Choi, S.Y.; Jung, N.C.; Song, J.Y.; Seo, H.G.; Lee, H.S.; Lim, D.S. The effect of the tumor microenvironment and tumor-derived metabolites on dendritic cell function. J. Cancer 2020, 11, 769-775. [CrossRef]

32. Nishimura, T.; Iwakabe, K.; Sekimoto, M.; Ohmi, Y.; Yahata, T.; Nakui, M.; Sato, T.; Habu, S.; Tashiro, H.; Sato, M.; et al. Distinct role of antigen-specific T helper type 1 (Th1) and Th2 cells in tumor eradication in vivo. J. Exp. Med. 1999, 190, 617-627. [CrossRef] [PubMed]

33. Nishimura, T.; Nakui, M.; Sato, M.; Iwakabe, K.; Kitamura, H.; Sekimoto, M.; Ohta, A.; Koda, T.; Nishimura, S. The critical role of Th1-dominant immunity in tumor immunology. Cancer Chemother. Pharmacol. 2000, 46, S52-S61. [CrossRef] 
34. Heufler, C.; Koch, F.; Stanzl, U.; Topar, G.; Wysocka, M.; Trinchieri, G.; Enk, A.; Steinman, R.M.; Romani, N.; Schuler, G. Interleukin-12 is produced by dendritic cells and mediates $\mathrm{T}$ helper 1 development as well as interferon-gamma production by $\mathrm{T}$ helper 1 cells. Eur. J. Immunol. 1996, 26, 659-668. [CrossRef] [PubMed]

35. Voest, E.E.; Kenyon, B.M.; O’Reilly, M.S.; Truitt, G.; D’Amato, R.J.; Folkman, J. Inhibition of angiogenesis in vivo by interleukin 12. J. Natl. Cancer Inst. 1995, 87, 581-586. [CrossRef]

36. Fu, C.; Jiang, A. Dendritic Cells and CD8 T Cell Immunity in Tumor Microenvironment. Front Immunol. 2018, 9. [CrossRef]

37. Li, P.; Yin, Y.L.; Li, D.; Kim, S.W.; Wu, G. Amino acids and immune function. Br. J. Nutr. 2007, 98, 237-252. [CrossRef]

38. Kakazu, E.; Ueno, Y.; Kondo, Y.; Fukushima, K.; Shiina, M.; Inoue, J.; Tamai, K.; Ninomiya, M.; Shimosegawa, T. Branched chain amino acids enhance the maturation and function of myeloid dendritic cells ex vivo in patients with advanced cirrhosis. Hepatology 2009, 50, 1936-1945. [CrossRef]

39. Kakazu, E.; Kanno, N.; Ueno, Y.; Shimosegawa, T. Extracellular branched-chain amino acids, especially valine, regulate maturation and function of monocyte-derived dendritic cells. J. Immunol. 2007, 179, 7137-7146. [CrossRef]

40. Helft, J.; Bottcher, J.; Chakravarty, P.; Zelenay, S.; Huotari, J.; Schraml, B.U.; Goubau, D.; Reis e Sousa, C. GM-CSF mouse bone marrow cultures comprise a heterogeneous population of $\mathrm{CD} 11 \mathrm{c}(+) \mathrm{MHCII}(+)$ macrophages and dendritic cells. Immunity 2015, 42,1197-1211. [CrossRef]

41. Wimmers, F.; Aarntzen, E.H.; Duiveman-deBoer, T.; Figdor, C.G.; Jacobs, J.F.; Tel, J.; de Vries, I.J. Long-lasting multifunctional CD8(+) T cell responses in end-stage melanoma patients can be induced by dendritic cell vaccination. Oncoimmunology 2016, 5, e1067745. [CrossRef]

42. Aktas, E.; Kucuksezer, U.C.; Bilgic, S.; Erten, G.; Deniz, G. Relationship between CD107a expression and cytotoxic activity. Cell Immunol. 2009, 254, 149-154. [CrossRef] [PubMed]

43. Ahrends, T.; Busselaar, J.; Severson, T.M.; Babala, N.; de Vries, E.; Bovens, A.; Wessels, L.; van Leeuwen, F.; Borst, J. CD4(+) T cell help creates memory CD8(+) T cells with innate and help-independent recall capacities. Nat. Commun. 2019, 10, 5531. [CrossRef] [PubMed]

44. Westerhof, L.M.; McGuire, K.; MacLellan, L.; Flynn, A.; Gray, J.I.; Thomas, M.; Goodyear, C.S.; MacLeod, M.K. Multifunctional cytokine production reveals functional superiority of memory CD4 T cells. Eur. J. Immunol. 2019, 49, 2019-2029. [CrossRef]

45. Takeuchi, A.; Saito, T. CD4 CTL, a Cytotoxic Subset of CD4(+) T Cells, Their Differentiation and Function. Front. Immunol. 2017, 8, 194. [CrossRef]

46. Quezada, S.A.; Simpson, T.R.; Peggs, K.S.; Merghoub, T.; Vider, J.; Fan, X.; Blasberg, R.; Yagita, H.; Muranski, P.; Antony, P.A.; et al. Tumor-reactive CD4(+) T cells develop cytotoxic activity and eradicate large established melanoma after transfer into lymphopenic hosts. J. Exp. Med. 2010, 207, 637-650. [CrossRef]

47. Yi, L.; Lakemond, C.M.; Sagis, L.M.; Eisner-Schadler, V.; van Huis, A.; van Boekel, M.A. Extraction and characterisation of protein fractions from five insect species. Food Chem. 2013, 141, 3341-3348. [CrossRef]

48. Bidlingmeyer, B.A.; Cohen, S.A.; Tarvin, T.L. Rapid analysis of amino acids using pre-column derivatization. J. Chromatogr. 1984, 336, 93-104. [CrossRef]

49. Matheu, M.P.; Sen, D.; Cahalan, M.D.; Parker, I. Generation of bone marrow derived murine dendritic cells for use in 2-photon imaging. J. Vis. Exp. 2008. [CrossRef]

50. Pietkiewicz, S.; Schmidt, J.H.; Lavrik, I.N. Quantification of apoptosis and necroptosis at the single cell level by a combination of Imaging Flow Cytometry with classical Annexin V/propidium iodide staining. J. Immunol. Methods 2015, 423, 99-103. [CrossRef]

51. Song, H.Y.; Sik Kim, W.; Kim, J.M.; Bak, D.H.; Moo Han, J.; Lim, S.T.; Byun, E.B. A hydroxyethyl derivative of chrysin exhibits anti-inflammatory activity in dendritic cells and protective effects against dextran sodium salt-induced colitis in mice. Int. Immunopharmacol. 2019, 77. [CrossRef]

52. Kim, W.S.; Yoon, J.H.; Shin, M.K.; Shin, S.J. Infection of dendritic cells with mycobacterium avium subspecies hominissuis exhibits a functionally tolerogenic phenotype in response to toll-like receptor agonists via IL-10/Cox2/PGE2/EP2 Axis. Front. Microbiol. 2019, 10, 1795. [CrossRef]

53. Kim, W.S.; Han, J.M.; Song, H.Y.; Byun, E.H.; Lim, S.T.; Byun, E.B. Annona muricata L.-derived Polysaccharides as a potential adjuvant to a dendritic cell-based vaccine in a Thymoma-bearing model. Nutrients 2020, 12, 1602. [CrossRef] 